\title{
Semi-annual variation of excited hydroxyl emission at mid-latitudes
}

\author{
Mykhaylo Grygalashvyly ${ }^{1}$, Alexander I. Pogoreltsev ${ }^{2}$, Alexey B. Andreyev ${ }^{3}$, Sergei P. Smyshlyaev ${ }^{2}$ and \\ Gerd R. Sonnemann ${ }^{1}$ \\ ${ }^{1}$ Leibniz Institute of Atmospheric Physics, University Rostock, Schloss-Str. 6, \\ 18225 Ostseebad Kühlungsborn, Germany \\ ${ }^{2}$ Department of Meteorological Forecasting, Russian State Hydrometeorological University (RSHU), \\ Saint Petersburg, Russia \\ ${ }^{3}$ Institute of the Ionosphere, National Center for Space Research and Technology, Almaty, Kazakhstan
}

Correspondence: Mykhaylo Grygalashvyly (gryga@iap-kborn.de)

Received: 27 November 2020 - Discussion started: 7 December 2020

Revised: 25 January 2021 - Accepted: 27 January 2021 - Published: 26 February 2021

\begin{abstract}
Ground-based observations show a phase shift in semi-annual variation of excited hydroxyl $\left(\mathrm{OH}^{*}\right)$ emissions at mid-latitudes $\left(43^{\circ} \mathrm{N}\right)$ compared to those at low latitudes. This differs from the annual cycle at high latitudes. We examine this behaviour by utilising an $\mathrm{OH}^{*}$ airglow model which was incorporated into a 3D chemistry-transport model (CTM). Through this modelling, we study the morphology of the excited hydroxyl emission layer at mid-latitudes (30$50^{\circ} \mathrm{N}$ ), and we assess the impact of the main drivers of its semi-annual variation: temperature, atomic oxygen, and air density. We found that this shift in the semi-annual cycle is determined mainly by the superposition of annual variations of temperature and atomic oxygen concentration. Hence, the winter peak for emission is determined exclusively by atomic oxygen concentration, whereas the summer peak is the superposition of all impacts, with temperature taking a leading role.
\end{abstract}

\section{Introduction}

Since the second half of the 20th century, emissions of excited hydroxyl have been used for three main purposes: (1) to infer information about temperature and its long-term change; (2) to obtain distributions of minor chemical constituents $\left(\mathrm{O}_{3}, \mathrm{H}\right.$, and $\left.\mathrm{O}\right)$ at the altitudes of the mesopause; and (3) to investigate dynamic processes such as tides, gravity, and planetary waves (GWs and PWs, respectively); sud- den stratospheric warmings (SSWs); and the quasi-biennial oscillation (QBO).

Hence, a number of authors have studied temperatures in the mesopause region using airglow emission ground-based observations focusing on long-term trends (e.g. Bittner et al., 2002; Holmen et al., 2014; Dalin et al., 2020, and references therein) with attention to seasonal variations (e.g. Reid et al., 2017, and references therein) and the solar-cycle effect (e.g. Kalicinsky et al., 2016, and references therein).

Minor chemical constituents as well as chemical heat have also been retrieved by $\mathrm{OH}^{*}$ emission observations. Ever since atomic oxygen concentration was determined by the rocket-borne detection of $\mathrm{OH}^{*}$ airglow (Good, 1976), this method has come into wide use for obtaining information about distributions of minor chemical constituents in the mesopause region, namely, atomic oxygen concentration (e.g. Russell et al., 2005; Mlynczak et al., 2013a, and references therein), ozone concentration (e.g. Smith et al., 2009, and references therein), atomic hydrogen concentration (e.g. Mlynczak et al., 2014, and references therein), and exothermic chemical heat (e.g. Mlynczak et al., 2013b, and references therein). In future, excited hydroxyl airglow could be used for measurements of hydroperoxy radicals and water vapour concentrations (Kulikov et al., 2009, 2018b; Belikovich et al., 2018b).

Numerous studies using airglow observations, have been devoted to dynamic processes, e.g. to study mesopause variabilities in time of SSWs (Damiani et al., 2010; Shepherd 
et al., 2010). Gao et al. (2011) studied the temporal evolution of nightglow brightness and height during SSW events. A year earlier, they found a QBO signal in the excited hydroxyl emission (Gao et al., 2010). The climatology of PWs was investigated in studies by Takahashi et al. (1999), Buriti et al. (2005), and Reisin et al. (2014). Tides were studied by $\mathrm{Xu}$ et al. (2010) and Lopez-Gonzalez et al. (2005). GW parameters based on the airglow technique were investigated, e.g. by Taylor et al. (1991) and Wachter et al. (2015). A more complete description of studies in which hydroxyl emissions were used to study dynamic processes can be found in a review by Shepherd et al. (2012).

The morphology of the $\mathrm{OH}^{*}$ layer is an essential component in the interpretation of observations and in understanding the processes involved in layer variability. Annual variations in the $\mathrm{OH}^{*}$ layer have been identified at all latitudes (Marsh et al., 2006). Equatorial and low-latitude semi-annual variations have been observed by satellites (e.g. Abreu and Yee, 1989; Liu et al., 2008, and references therein), as well as by ground-based instruments (Takahashi et al., 1995), and they have been modelled by several research teams (Le Texier et al., 1987; Marsh et al., 2006, and references therein). The maxima of emissions were found to occur near equinoxes. In spite of the large number of studies on this subject, there are still knowledge gaps. Recently, unexpected behaviour in the semi-annual cycle of excited hydroxyl emission has been found by ground-based observations, with a shift of the peaks from equinoxes to summer and winter at middle latitudes (Popov et al., 2018, 2020); this was also found by modelling (Grygalashvyly et al., 2014; Fig. 3). Similar variations in $\mathrm{OH}^{*}$ emissions with peaks near equinoxes have been observed at middle latitudes $\left(34.6^{\circ} \mathrm{N}\right)$ in the Southern Hemisphere (Reid et al., 2014). These results were provided without explanations; in our short paper, we offer a preliminary explanation.

The second section of our article describes the observational technique and model that were applied; in the third section, we present results and an analysis of observations and modelling; conclusions are provided in the fourth section.

\section{Observational technique and model}

\subsection{Observational technique}

The spectral airglow temperature imager (SATI), which measures nightglow intensity for vibrational transitions of $\mathrm{OH}_{v=6}^{*} \rightarrow \mathrm{OH}_{v=2}^{*}$ and temperature using vibrationalrotational transitions, was assembled at the Institute of Ionosphere $\left(43^{\circ} \mathrm{N}, 77^{\circ} \mathrm{E}\right)$ in Almaty, Kazakhstan. It represents a Fabry-Perot spectrometer with a CCD (charge-coupled device) camera as a detector and a narrowband interference filter as the etalon. Following Lopez-Gonzalez et al. (2007), we use an interference filter with the centre at $836.813 \mathrm{~nm}$ and a bandwidth of $0.182 \mathrm{~nm}$. This corresponds to the spectral region of the $\mathrm{OH}_{v=6}^{*} \rightarrow \mathrm{OH}_{v=2}^{*}$ band. In order to infer the temperature, the calculated spectra for different vibro-rotational transitions are compared with those from observations. The SATI operates at a $60 \mathrm{~s}$ exposure that provides corresponding time resolution. The method of temperature retrieval is well-described by Lopez-Gonzalez et al. (2004). The observations of temperature were validated using satellite SABER measurements (Lopez-Gonzalez et al., 2007; Pertsev et al., 2013). Additional details about this instrument are presented in many papers (Wies et al., 1997; Aushev et al., 2000; Lopez-Gonzalez et al., 2004, 2005, 2007, 2009). The analysis presented in this paper uses data averaged over the years 2010-2017.

\subsection{Model and numerical experiment}

The model of excited hydroxyl (MEH) calculates the $\mathrm{OH}^{*}$ number densities at each vibrational level $v$ as the production divided by losses (excited hydroxyl is assumed in the photochemical equilibrium), which include the chemical sources as well as collisional and emissive removal:

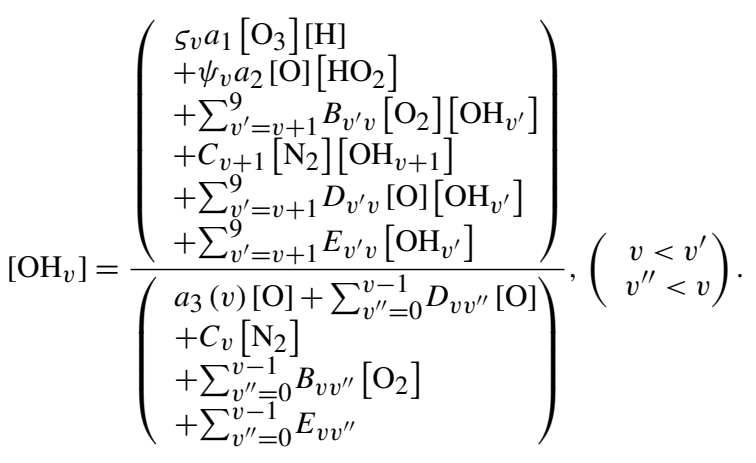

The first term in the numerator of Eq. (1) is the reaction $\mathrm{O}_{3}+\mathrm{H} \rightarrow \mathrm{OH}_{v}+\mathrm{O}$, where $a_{1}$ is the reaction rate, and $\varsigma_{v}$ represents the branching ratios (Adler-Golden, 1997). The second term is the $\mathrm{O}+\mathrm{HO}_{2} \rightarrow \mathrm{OH}_{v}+\mathrm{O}_{2}$ reaction, where $a_{2}$ and $\psi_{v}$ are the reaction rate and nascent distribution, respectively (Kaye, 1988, after Takahashi and Batista, 1981). The other three summands represent the populations resulting from collisional relaxation from higher $v$ levels, where $B, C$, and $D$ are the collisional deactivation coefficients for $\mathrm{O}_{2}$ (Adler-Golden, 1997), $\mathrm{N}_{2}$ (Makhlouf et al., 1995), and O (Caridade et al., 2013), respectively. The last summand is the multi-quantum population by spontaneous emissions, where $E_{v^{\prime} v}$ is the spontaneous emission coefficient (Xu et al., 2012). The losses occur, additionally, through the chemical removal of the excited hydroxyl by atomic oxygen, where $a_{3}(v)$ is the vibrationally dependent reaction rate (Varandas, 2004). The calculations in Eq. (1) are incorporated into the chemistry-transport model (CTM). We calculate volume emission for transition $\mathrm{OH}_{v=6}^{*} \rightarrow \mathrm{OH}_{v=2}^{*}$ as the product of the Einstein coefficient for given transition by concentration of excited hydroxyl at corresponding vibrational number, i.e. 
Table 1. List of reactions with corresponding reaction rates (for three-body reactions $\left[\mathrm{cm}^{6}\right.$ molecule ${ }^{-2} \mathrm{~s}^{-1}$ ] and for two-body reactions $\left[\mathrm{cm}^{3}\right.$ molecule $\left.\left.\mathrm{e}^{-1} \mathrm{~s}^{-1}\right]\right)$, branching ratios, quenching coefficients, and spontaneous emission coefficients $\left(\mathrm{s}^{-1}\right)$ used in the paper.

\begin{tabular}{llll}
\hline \multicolumn{1}{c}{ Reaction } & Coefficient or branching ratios & Reference \\
\hline 1 & $\mathrm{H}+\mathrm{O}_{3} \stackrel{5 v a a_{1}}{\longrightarrow} \mathrm{OH}_{v=5, \ldots, 9}+\mathrm{O}_{2}$ & $\begin{array}{l}a_{1}=1.4 \times 10^{-10} \exp \left(\frac{-470}{T}\right) \\
\begin{array}{l}5 v=9, \ldots, 5= \\
0.47,0.34,0.15,0.03,0.01\end{array}\end{array}$ & $\begin{array}{l}\text { Burkholder et al. (2015), Adler-Golden } \\
(1997)\end{array}$ \\
\hline 2 & $\mathrm{O}+\mathrm{HO}_{2} \stackrel{\psi_{v} a_{2}}{\longrightarrow} \mathrm{OH}_{\mathrm{v}=5, \ldots, 9}+\mathrm{O}_{2}$ & $\begin{array}{l}a_{2}=3.0 \times 10^{-11} \exp \left(\frac{200}{T}\right) \\
\psi_{v=3, \ldots, 1}=0.1,0.13,0.34\end{array}$ & $\begin{array}{l}\text { Burkholder et al. (2015), Kaye (1988), } \\
\text { Takahashi and Batista (1981) }\end{array}$ \\
\hline 3 & $\mathrm{O}+\mathrm{OH}_{\mathrm{v}=1, \ldots, 9 \rightarrow \mathrm{O}_{2}+\mathrm{H}}$ & $\begin{array}{l}a_{3}(v=9, \ldots, 5)=(5.07, \\
4.52,3.87,3.93,3.22,3.68,\end{array}$ & Varandas (2004), Caridade et al. (2013) \\
& & $3.05,3.19,3.42) \times 10^{-11}$ & \\
\hline 4 & $\mathrm{O}+\mathrm{O}_{2}+M \rightarrow \mathrm{O}_{3}+M$ & $a_{4}=6 \times 10^{-34}(300 / T)^{2.4}$ & Burkholder et al. (2015) \\
\hline 5 & $\mathrm{O}+\mathrm{O}_{3} \rightarrow 2 \mathrm{O}_{2}$ & $a_{5}=8 \times 10^{-12} \exp \left(\frac{-2060}{T}\right)$ & Burkholder et al. (2015) \\
\hline 6 & $\mathrm{OH}_{\mathrm{v}}+\mathrm{O}_{2}, \mathrm{O}, \mathrm{N}_{2} \rightarrow \mathrm{OH}_{\mathrm{v}^{\prime}<\mathrm{v}}+$ & $B_{v v^{\prime}}, D_{v v^{\prime}}, C_{v v^{\prime}}$ & $\begin{array}{l}\text { Adler-Golden (1997), Caridade et al. } \\
\text { (2013), Makhlouf et al. (1995) }\end{array}$ \\
\hline 7 & $\mathrm{O}_{2}, \mathrm{O}_{2} \mathrm{~N}_{2}$ & $\mathrm{OH}_{\mathrm{v}} \rightarrow \mathrm{OH}_{\mathrm{v}^{\prime}<\mathrm{v}}+h v$ & Xu et al. (2012) \\
\hline
\end{tabular}

$V_{62}=E_{62}\left[\mathrm{OH}_{6}^{*}\right]$. All reactions used in Eq. (1) and in the appendix - together with corresponding reaction rates, branching ratios, quenching rates, and spontaneous emission coefficients, besides those for multi-quantum processes - are collected in Table 1.

Here, we enumerate only the main features of the CTM as one can find extended descriptions in many studies (Sonnemann and Grygalashvyly, 2020; Grygalashvyly et al., 2014; and references therein). The CTM consists of four blocks: chemical, transport, radiative, and diffusive. The chemical block accounts for 19 constituents and 63 photodissociations and chemical reactions (Burkholder et al., 2015). The chemical code utilises a family approach with the odd oxygen $\left(\mathrm{O}\left({ }^{1} \mathrm{D}\right), \mathrm{O}, \mathrm{O}_{3}\right)$, odd hydrogen $\left(\mathrm{H}, \mathrm{OH}, \mathrm{HO}_{2}, \mathrm{H}_{2} \mathrm{O}_{2}\right)$, and odd nitrogen $\left(\mathrm{N}\left({ }^{2} \mathrm{D}\right), \mathrm{N}\left({ }^{4} \mathrm{~S}\right), \mathrm{NO}, \mathrm{NO}_{2}\right)$ families (Shimazaki, 1985). In the radiative part, the dissociation rates are taken from a precalculated table depending on zenith angle and altitude (Kremp et al., 1999). The transport block calculates advection in three directions following Walcek (2000). The diffusive part accounts for only vertical molecular plus turbulent diffusion (Morton and Mayers, 1994). This model has been validated against observations of ozone, which plays a role in the formation of $\mathrm{OH}^{*}$ (e.g. Hartogh et al., 2011; Sonnemann et al., 2007; and references therein) and water vapour, which is the principal source of odd hydrogens and, particularly, of atomic hydrogen (e.g. Hartogh et al., 2010; Sonnemann et al., 2008; and references therein). Our current analysis used the run for year 2009 (the choice of this year does not affect our conclusions, because calculations for other years show similar semi-annual variations), which was published and described in a number of studies (Grygalashvyly et al.,
2014, Sect. 4; Sonnemann et al., 2015). This run is based on the dynamics and temperature of the LIMA (Leibniz Institute Middle Atmosphere) model for the so-called "realistic case", in which carbon dioxide, ozone, and Lyman- $\alpha$ flux are taken from observations, and the horizontal winds and temperature of ECMWF (European Centre for Medium-Range Weather Forecasts) are assimilated below $\sim 35 \mathrm{~km}$ (Berger, 2008; Lübken et al., 2009, 2013).

Here we assume that the structures in the longitudinal direction are equivalent to local time (LT) behaviour, with 24:00 LT related to midnight at $0^{\circ}$ longitude. The local times of successive longitudes are used to analyse our calculations. Hence, in the following figures related to the model results, longitude is used as the so-called "pseudo time". The night-time averaged values account for the period from 21:45 to 02:15 LT. For the purposes of our discussion, we use "pressure-altitude" (or in other words "pseudoaltitude") $Z^{*}=-H \ln \left(P / P_{0}\right)$, where $P$ represents pressure, $P_{0}=1013$ mbar is the surface pressure, and $H=7 \mathrm{~km}$ is the scale height.

\section{Results and discussion}

Figure 1a illustrates the nightly mean monthly averaged values of the observed annual variability of intensity at $43^{\circ} \mathrm{N}$ (red line) and the modelled annual variability of volume emission at the peak of the $\mathrm{OH}^{*}$ layer at $43.75^{\circ} \mathrm{N}$ (black line), both for transition $\mathrm{OH}_{v=6}^{*} \rightarrow \mathrm{OH}_{v=2}^{*}$. The error bar shows monthly $\mathrm{SD}$, because we display monthly mean values, and SDs commonly exceed the errors of measurements. By the observations as well as by modelling, we can clearly 

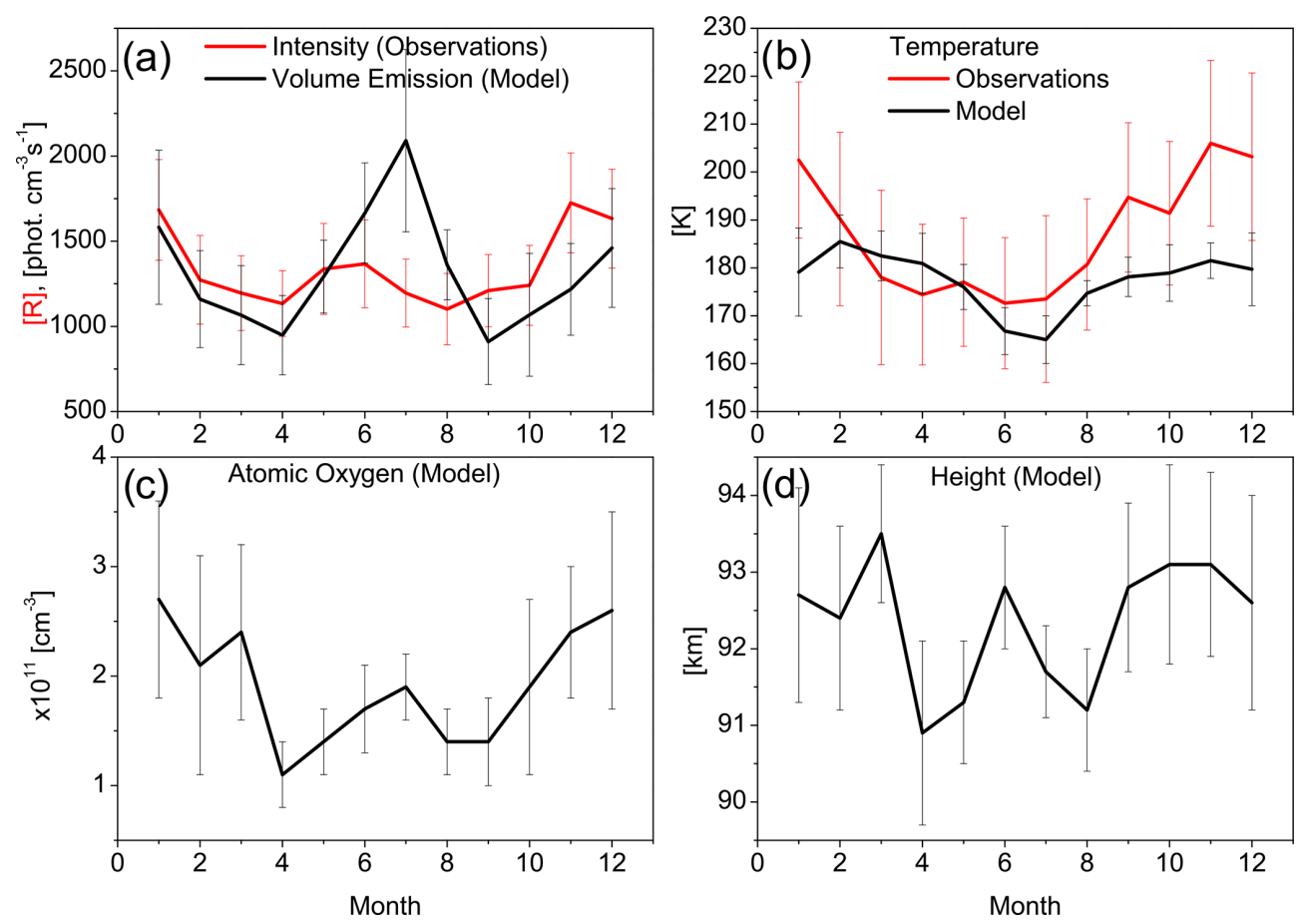

Figure 1. Observed at $43^{\circ} \mathrm{N}$ (red line) and modelled at $43.75^{\circ} \mathrm{N}$ (black line), annual variability of intensity and volume emission (a), temperature (b), atomic oxygen concentration (c), and height at the peak of the $\mathrm{OH}_{v=6}^{*}$ layer.

see semi-annual variations of emissions with peaks in winter and summer. Note that the observed intensity is directly proportional to the vertical integral of the volume emissions; hence, they reveal similar variations and dependencies on surrounding conditions near the peak of the excited hydroxyl layer.

Grygalashvyly et al. (2014), Sonnemann et al. (2015), and Grygalashvyly (2015) have derived and confirmed through modelling that the concentration of excited hydroxyl (hence, volume emission and intensity) at peak is directly proportional to the product of the surrounding pressure (hence, it depends on altitude), atomic oxygen number density, and the negative power of temperature (Eq. A2 in the appendix). Thus, in order to infer the reasons for this semi-annual variation, one should consider three drivers of $\mathrm{OH}^{*}$ variability: temperature, atomic oxygen concentration, and height of the layer.

Figure $1 \mathrm{~b}$ shows the monthly mean nightly averaged values of the observed annual variability of temperature at $43^{\circ} \mathrm{N}$ (red line) and the modelled annual variability of temperature at the $\mathrm{OH}_{v=6}^{*}$ peak at $43.75^{\circ} \mathrm{N}$ (black line). Both the observations and the modelling show minima in summer and maxima in winter. Hence, the temperature decline can be one of the reasons for the summer intensity (and volume emission) peak.

Figure 1c and d depicts modelled monthly mean nightly averaged values of atomic oxygen at $\mathrm{OH}_{v=6}^{*}$ peak and the height of the excited hydroxyl peak, respectively, at $43.75^{\circ} \mathrm{N}$. The modelling shows the peaks of atomic oxygen concentration in July and December-January, with the largest values in winter. The variation of height through the year occurs from $\sim 90$ to $94 \mathrm{~km}$. This is an essential variability and provides input to the variability of the concentration of the surrounding air.

In order to study the morphology of this semi-annual variation and assess the impacts of temperature, atomic oxygen concentration, and height (concentration of air) variability, we calculate 1-month sliding averaged values based on the model results. Figure 2 illustrates the modelled annual variability at the $\mathrm{OH}_{v=6}^{*}$ peak: (a) volume emission $\left(\mathrm{OH}_{v=6}^{*} \rightarrow \mathrm{OH}_{v=2}^{*}\right)$, (b) temperature, (c) atomic oxygen concentration, and (d) height of the peak.

The summer maximum of volume emission (Fig. 2a) shows the strongest values in July and is extended from $\sim 30$ to $\sim 50^{\circ} \mathrm{N}$. The summer maximum is stronger than that in winter. The winter maximum has its strongest values in January and a positive gradient into the winter pole direction; at latitudes $30-50^{\circ} \mathrm{N}$, it represents the part of the annual variation at high latitudes that occurs because of the annual variation in general mean circulation and fluxes of atomic oxygen which correspond to this variability (Liu et al., 2008; Marsh et al., 2006). Similar behaviour of the emissions for transition $\mathrm{OH}_{\mathrm{v}=8}^{*} \rightarrow \mathrm{OH}_{\mathrm{v}=3}^{*}$ was captured by WINDII (Wind Imaging Interferometer) and modelled by the ThermosphereIonosphere-Mesosphere Electrodynamics general circulation model at 84-88 km (Liu et al., 2008; Figs. 5 and 6). 

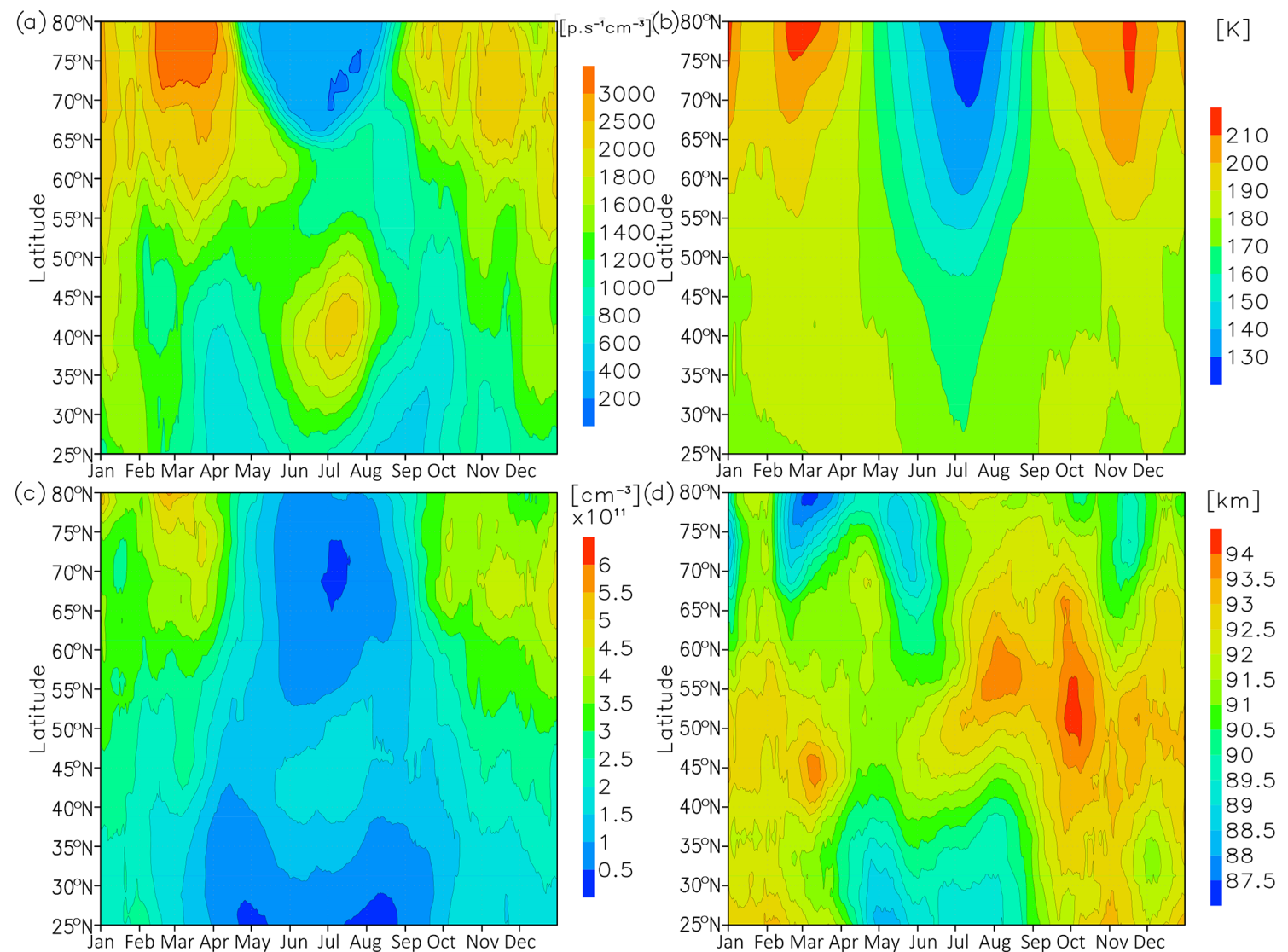

Figure 2. Nightly mean 1-month sliding average volume emission (a), temperature (b), atomic oxygen at peak of $\mathrm{OH}_{v=6}^{*}(\mathbf{c})$, and height of peak of $\mathrm{OH}_{v=6}^{*}$.

The temperature (Fig. 2b) shows a clear annual variation from the middle to the high latitudes, with a minimum $\sim 150 \mathrm{~K}$ at middle latitudes in July. The summer minimum at the middle latitudes is the echo of the one at high latitudes. The atomic oxygen concentrations (Fig. 2c) reveal the annual cycle. The concentrations have a maximum in winter and a minimum in summer at high and middle latitudes, as has already been observed (Smith et al., 2010). However, in the region from $\sim 30$ to $\sim 50^{\circ} \mathrm{N}$ in summer, atomic oxygen concentrations show one additional peak in June-July. Formation of this summer peak can be explained by the transformed Eulerian mean (TEM) circulation (Limpasuvan et al., 2012; Fig. 7; Limpasuvan et al., 2016; Fig. 5), which brings into the summer hemisphere the air reached by atomic oxygen from the region of its production at high latitudes above 100 to $\sim 90 \mathrm{~km}$ at $\sim 30-50^{\circ} \mathrm{N}$. The peak altitude of the $\mathrm{OH}_{v=6}^{*}$ peak (Fig. 2d) shows complex annual variability. There is a secondary maximum $\mathrm{OH}^{*}$ peak at $\sim 30-50^{\circ} \mathrm{N}$ in summer.

In order to assess the input into annual variability from different sources, we calculate relative to annually averaged variations of volume emissions due to atomic oxygen, tem- perature, and air density:

$$
\begin{aligned}
& \mathrm{RD}_{\mathrm{O}}^{\prime}=100 \% \cdot \frac{V_{\mathrm{O}}^{\prime}}{\bar{V}}=100 \% \cdot \frac{[\mathrm{O}]^{\prime}}{\overline{[\mathrm{O}]}}, \\
& \mathrm{RD}_{T}^{\prime}=100 \% \cdot \frac{V_{T}^{\prime}}{\bar{V}}=100 \% \cdot-2.4 \frac{T^{\prime}}{\bar{T}}, \\
& \mathrm{RD}_{M}^{\prime}=100 \% \cdot \frac{V_{M}^{\prime}}{\bar{V}}=100 \% \cdot \frac{[M]^{\prime}}{\overline{[M]}},
\end{aligned}
$$

where overbar denotes annually averaged values, and prime denotes difference of actual (modelled or observed) values from annually averaged values (in our case this is the difference between nightly mean 1-month sliding averaged values (Fig. 2) and nightly mean annually averaged values). The derivation of these parameters is presented in the appendix. A similar approach can be useful for analysing emission variations due to GWs, PWs, and tides.

Figure 3 a shows relative variations of emissions due to impacts of atomic oxygen (black line), temperature (red line), and air density (green line) at $43.75^{\circ} \mathrm{N}$. The strongest emission variation occurs because of changes in atomic oxygen concentration: the amplitude of its relative deviation amounts to $\sim 50 \%$. The amplitudes of relative deviations of emissions 

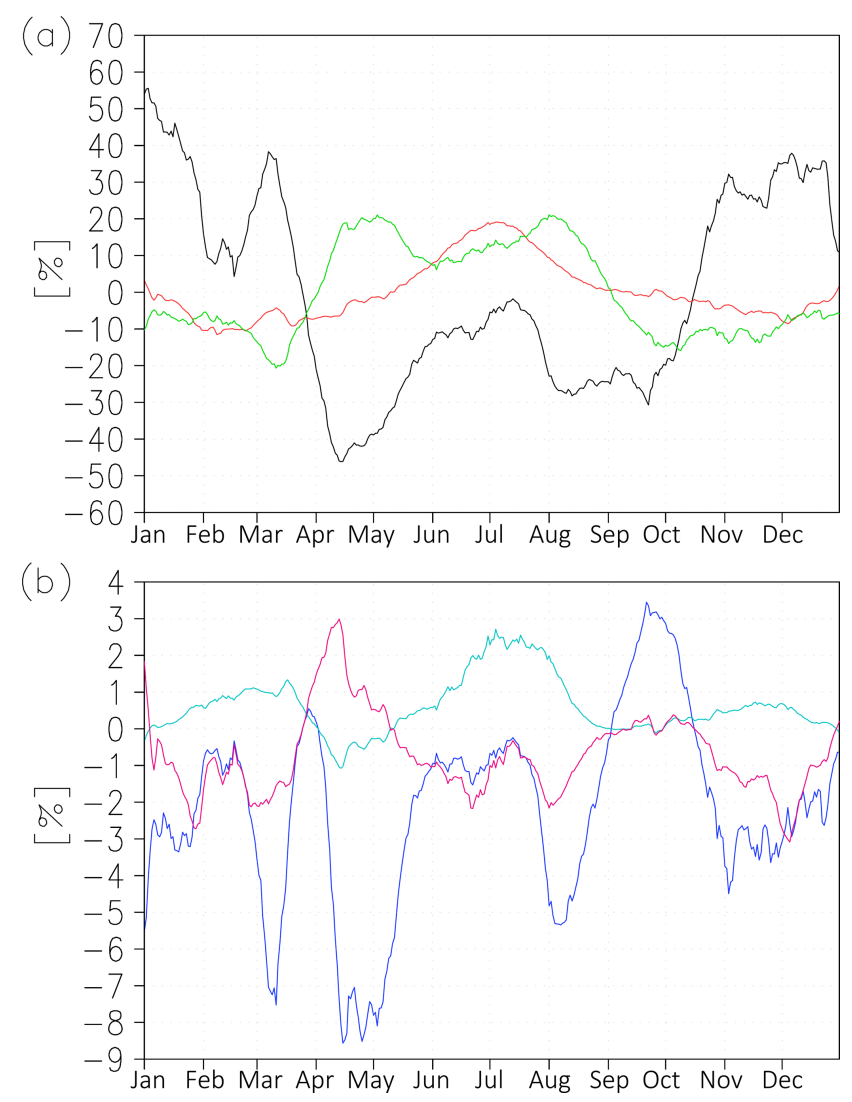

Figure 3. (a) Relative to annually averaged variations of volume emission (Eq. 2) due to atomic oxygen (black line), temperature (red line), and height (green line) at $43.75^{\circ} \mathrm{N}$. (b) Relative variations of volume emissions due to second momentum $\frac{[\mathrm{O}]^{\prime} M^{\prime}}{\overline{[\mathrm{O}] M}}$ (blue line), $\frac{T^{\prime} M^{\prime}}{\overline{T M}}$ (cyan line), and $\frac{[\mathrm{O}]^{\prime} T^{\prime}}{\overline{[\mathrm{O}] \bar{T}}}$ (magenta line) at $43.75^{\circ} \mathrm{N}$.

due to temperature and air density amount to $\sim 15 \%$ and $\sim 20 \%$, respectively. The atomic oxygen variation gives the most essential input into the winter maximum of emission (black line). Because of the downward transport of atomic oxygen in winter, the volume emission rises by $\sim 50 \%$ of annual average. The summer maximum is determined by the superposition of all three factors. After the spring reduction of emissions due to the decline of atomic oxygen concentration ( $\sim-40 \%$ of annually averaged values), the emissions rise again to approximately the annual average values in June-July. This is synchronised with the growth of volume emissions by $\sim 20 \%$ over the annual average values due to summer temperature declines (red line) and with the growth of volume emissions by $\sim 15 \%$ over the annual average due to the decline of peak altitude in April-September and the corresponding rise of air density (green line).

Figure $3 b$ illustrates relative variations of emissions due to second momenta (Eq. A7 in the appendix). The second momenta do not provide essential input to annual variation. The strongest among them, $\frac{[\mathrm{O}]^{\prime} M^{\prime}}{\overline{[\mathrm{O}] \bar{M}}}$ (blue line), gives emission variability with an amplitude of $\sim 6 \%$ of annually averaged values.

In the context of our short paper, the ultimate question regarding the role of tides and GWs on semi-annual variations of $\mathrm{OH}^{*}$ emissions at middle latitudes has not been answered. Undoubtedly, the simultaneous analysis of observations of excited hydroxyl emissions from several stations is desirable to explore this question.

\section{Summary and conclusions}

Based on observations and numerical simulation, we confirmed the existence of a semi-annual cycle of excited hydroxyl emission at middle latitudes with maxima in summer (June-July) and winter (December-January). The annual variation in general mean circulation and atomic oxygen concentration corresponding to the excited hydroxyl emission cycle was found to be the leading cause of the winter maximum of this cycle, whereas the summer maximum represents the superposition of three different processes: atomic oxygen meridional transport due to residual circulation from the summer pole to the Equator; temperature decline, which represents the rest of the mesopause cooling at summer high latitudes; and air concentration growth at the peak of the excited hydroxyl emission layer due to hydroxyl layer descent at middle latitudes in April-September. 


\section{Appendix A}

To obtain the derivation of Eq. (2), we start with a simplified equation for excited hydroxyl concentration. Taking into account that the ozone is in photochemical equilibrium in the vicinity of the $\left[\mathrm{OH}_{v}\right]$ layer and above during nighttime (Kulikov et al., 2018a, 2019; Belikovich et al., 2018a); utilising the equation for ozone balance during night-time $\left(a_{5}\left[\mathrm{O}_{3}\right][\mathrm{O}]+a_{1}[\mathrm{H}]\left[\mathrm{O}_{3}\right]=a_{4}[\mathrm{O}]\left[\mathrm{O}_{2}\right][M]\right)$, where $a_{4}$ and $a_{5}$ are the coefficients for the corresponding reactions; omitting the reaction of atomic oxygen with ozone as relatively slow (Smith et al., 2008); substituting the reduced ozone balance equation for the excited hydroxyl balance equation (first term in the numerator of Eq. 1); assuming that the most effective production of excited hydroxyl occurs due to the reaction of ozone with atomic hydrogen and that the most effective losses are due to quenching with molecular oxygen; we obtain from Eq. (1) a simplified expression in which excited hydroxyl concentration is represented in terms of atomic oxygen concentration, temperature (in $a_{4}$ ), and concentration of the surrounding air:

$\left[\mathrm{OH}_{v}\right] \approx \mu_{v} a_{4}[\mathrm{O}][M]$

Here $\mu_{v}=\frac{\varsigma_{v}+\sum_{v^{\prime}=v+1}^{v^{\prime}=9} \mu_{v^{\prime}} B_{v^{\prime} v}}{\sum_{v^{\prime \prime}=0}^{v^{\prime \prime}=0-1} B_{v v^{\prime \prime}}},\left(\varsigma_{v>9}=0\right)$ represents the coefficients representing the arithmetic combination of branching ratios $\varsigma_{v}$ and quenching coefficients $B_{v^{\prime} v}$. More comprehensive derivations of Eq. (A1) can be found in a number of papers (Grygalashvyly et al., 2014; Grygalashvyly, 2015; Grygalashvyly and Sonnemann, 2020). Although the accuracy of the Eq. (A1) estimate is insufficient for model calculations, it is useful for obtaining information about impacts and for assessing variabilities.

By multiplying Eq. (A1) by the Einstein coefficient $E_{v v^{\prime \prime}}$ for a given transition, writing the reaction rate explicitly $a_{4}=6 \times 10^{-34}(300 / T)^{2.4}$ (Burkholder et al., 2015), and collecting all constants in $\chi_{v v^{\prime \prime}}$, we obtain an expression for volume emission in terms of atomic oxygen concentration, temperature, and air number density:

$V \approx \chi_{v v^{\prime \prime}} T^{-2.4}[\mathrm{O}][M]$,

where $\chi_{v v^{\prime \prime}}=\mu_{v} E_{v v^{\prime \prime}} \cdot 6 \times 10^{-34} \cdot 300^{2.4}$.

Next, we apply Reynolds decomposition by averaged parts and variable parts to the temperature, atomic oxygen concentration, and concentration of air in Eq. (A2):

$V \approx \chi_{v v^{\prime \prime}}\left(\bar{T}+T^{\prime}\right)^{-2.4}\left(\overline{[\mathrm{O}]}+[\mathrm{O}]^{\prime}\right)\left(\overline{[M]}+[M]^{\prime}\right)$,

where $\bar{T}, \overline{[\mathrm{O}]}$, and $\overline{[M]}$ are average parts, and $T^{\prime},[\mathrm{O}]^{\prime}$, and $[M]^{\prime}$ are the corresponding varying parts.

After decomposing the term with temperature in the Taylor expansion and cross-multiplying all terms of Eq. (A3), we obtain

$$
\begin{aligned}
V \approx & \chi_{v v^{\prime \prime}} \bar{T}^{-2.4} \overline{[\mathrm{O}]} \cdot \overline{[M]}+\chi_{v v^{\prime \prime}} \bar{T}^{-2.4} \overline{[\mathrm{O}]}[M]^{\prime} \\
& +\chi_{v v^{\prime \prime}} \bar{T}^{-2.4}[\mathrm{O}]^{\prime} \overline{[M]}-2.4 \chi_{v v^{\prime \prime}} T^{\prime} \bar{T}^{-3.4} \overline{[\mathrm{O}]} \cdot \overline{[M]} \\
& +\chi_{v v^{\prime \prime}} \bar{T}^{-2.4}[\mathrm{O}]^{\prime}[M]^{\prime}-2.4 \chi_{v v^{\prime \prime}} T^{\prime} \bar{T}^{-3.4} \overline{\mathrm{O}]}[M]^{\prime} \\
& -2.4 \chi_{v v^{\prime \prime}} T^{\prime} \bar{T}^{-3.4}[\mathrm{O}]^{\prime}[M]-2.4 \chi_{v v^{\prime \prime}} T^{\prime} \bar{T}^{-3.4}[\mathrm{O}]^{\prime}[M]^{\prime} .
\end{aligned}
$$

The volume emission for a given transition can be represented as follows:

$$
\begin{aligned}
V \approx & \bar{V}+V_{M}^{\prime}+V_{\mathrm{O}}^{\prime}+V_{T}^{\prime}+V_{\mathrm{O} M}^{\prime \prime}+V_{T M}^{\prime \prime}+V_{T \mathrm{O}}^{\prime \prime} \\
& + \text { higher momenta, }
\end{aligned}
$$

where $\bar{V}=\chi_{v v^{\prime \prime}} \bar{T}^{-2.4} \overline{[\mathrm{O}]} \cdot \overline{[M]}, \quad V_{M}^{\prime}=\chi_{v v^{\prime \prime}} \bar{T}^{-2.4} \overline{[\mathrm{O}]}[M]^{\prime}$, $V_{\mathrm{O}}^{\prime}=\chi_{v v^{\prime \prime}} \bar{T}^{-2.4}[\mathrm{O}]^{\prime} \overline{[M]}, V_{T}^{\prime}=-2.4 \chi_{v v^{\prime \prime}} T^{\prime} \bar{T}^{-3.4} \overline{[\mathrm{O}]} \cdot \overline{[M]}$, $V_{\mathrm{O} M}^{\prime \prime}=\chi_{v v^{\prime \prime}} \bar{T}^{-2.4}[\mathrm{O}]^{\prime}[M]^{\prime}, \quad V_{T M}^{\prime \prime}=-2.4 \chi_{v v^{\prime \prime}} T^{\prime} \bar{T}^{-3.4}$ $\overline{[\mathrm{O}]}[M]^{\prime}$, and $V_{T \mathrm{O}}^{\prime \prime}=-2.4 \chi_{v v^{\prime \prime}} T^{\prime} \bar{T}^{-3.4}[\mathrm{O}]^{\prime} \overline{[M]}$.

Hence, relative deviations (RDs) of emissions due to variations in atomic oxygen, temperature, and concentration of air are

$$
\begin{aligned}
& \mathrm{RD}_{\mathrm{O}}^{\prime}=100 \% \cdot \frac{V_{\mathrm{O}}^{\prime}}{\bar{V}}=100 \% \cdot \frac{[\mathrm{O}]^{\prime}}{\overline{[\mathrm{O}]}}, \\
& \mathrm{RD}_{T}^{\prime}=100 \% \cdot \frac{V_{T}^{\prime}}{\bar{V}}=100 \% \cdot-2.4 \frac{T^{\prime}}{\bar{T}}, \\
& \mathrm{RD}_{M}^{\prime}=100 \% \cdot \frac{V_{M}^{\prime}}{\bar{V}}=100 \% \cdot \frac{[M]^{\prime}}{\overline{[M]}} .
\end{aligned}
$$

The relative deviations (RDs) of emissions due to second momenta are

$$
\begin{aligned}
& \mathrm{RD}_{\mathrm{O} M}^{\prime \prime}=100 \% \cdot \frac{V_{\mathrm{O} M}^{\prime \prime}}{\bar{V}}=100 \% \cdot \frac{[\mathrm{O}]^{\prime}[M]^{\prime}}{\overline{[\mathrm{O}][M]}}, \\
& \mathrm{RD}_{T M}^{\prime \prime}=100 \% \cdot \frac{V_{T M}^{\prime \prime}}{\bar{V}}=100 \% \cdot-2.4 \frac{T^{\prime}[M]^{\prime}}{\overline{T[M]}}, \\
& \mathrm{RD}_{T \mathrm{O}}^{\prime \prime}=100 \% \cdot \frac{V_{T \mathrm{O}}^{\prime \prime}}{\bar{V}}=100 \% \cdot-2.4 \frac{T^{\prime}[\mathrm{O}]^{\prime}}{\overline{T[\mathrm{O}]}} .
\end{aligned}
$$


Data availability. The data utilised in this article can be downloaded from http://ra.rshu.ru/files/Grygalashvyly_et_al_ANGEO_ 2020 (Grygalashvyly, 2020).

Author contributions. MG, AIP, ABA, SPS, and GRS were working on analysis of the observations, analysis of numerical simulations, preparing visualisation, and on writing the text.

Competing interests. The authors declare that they have no conflict of interest.

Acknowledgements. The authors are thankful to topical editor Petr Pisoft for help in evaluating this paper and to two anonymous referees for their constructive comments and improvements to the paper.

Financial support. This research has been supported by the Russian Science Foundation (grant nos. 20-77-10006 and FSZU2020-0009) and the Ministry of Science and Higher Education of the Russian Federation (grant no. FSZU-2020-0009).

The publication of this article was funded by the Open Access Fund of the Leibniz Association.

Review statement. This paper was edited by Petr Pisoft and reviewed by two anonymous referees.

\section{References}

Abreu, V. J. and Yee, J. H.: Diurnal and seasonal variation of the nighttime $\mathrm{OH}$ (8-3) emission at low latitudes, J. Geophys. Res., 94, 11949-11957, https://doi.org/10.1029/89JA00619, 1989.

Adler-Golden, S.: Kinetic parameters for $\mathrm{OH}$ nightglow modeling consistent with recent laboratory measurements, J. Geophys. Res., 102, 19969-19976, https://doi.org/10.1029/97JA01622, 1997.

Aushev, V. M., Pogoreltsev, A. I., Vodyannikov, V. V., Wiens, R. H., and Shepherd, G. G.: Results of the airglow and temperature observations by MORTI at the Almaty site $(43.05 \mathrm{~N}, 76.97 \mathrm{E})$, Phys. Chem. Earth, 25, 409-415, https://doi.org/10.1016/S14641909(00)00035-6, 2000.

Belikovich, M. V., Kulikov, M. Y., Grygalashvyly, M., Sonnemann, G. R., Ermakova, T. S., Nechaev, A. A., and Feigin, A. M.: Ozone chemical equilibrium in the extended mesopause under the nighttime conditions, Adv. Space Res., 61, 426-432, https://doi.org/10.1016/j.asr.2017.10.010, 2018a.

Belikovich, M. V., Kulikov, M. Y., Nechaev, A. A., Feigin, A. M.: Evaluation of the Atmospheric Minor Species Measurements: a Priori Statistical Constraints Based on Photochemical Modeling, Radiophys. Quantum El., 61, 574-588, https://doi.org/10.1007/s11141-019-09918-5, 2018b.
Berger, U.: Modeling of the middle atmosphere dynamics with LIMA, J. Atmos. Terr. Phys., 70, 1170-1200, https://doi.org/10.1016/j.jastp.2008.02.004, 2008.

Bittner, M., Offermann, D., Graef, H.-H., Donner, M., and Hamilton, $\mathrm{K}$.: An 18 year time series of $\mathrm{OH}$ rotational temperatures and middle atmosphere decadal variations, J. Atmos. Sol.-Terr. Phy., 64, 1147-1166, https://doi.org/10.1016/S1364-6826(02)000652, 2002.

Buriti, R. A., Takahashi, H., Lima, L. M., and Medeiros, A. F.: Equatorial planetary waves in the mesosphere observed by airglow periodic oscillations, Adv. Space Res., 35, 2031-2036, https://doi.org/10.1016/j.asr.2005.07.012, 2005.

Burkholder, J. B., Sander, S. P., Abbatt, J., Barker, J. R., Huie, R. E., Kolb, C. E., Kurylo, M. J., Orkin, V. L., Wilmouth, D. M., and Wine, P. H.: Chemical Kinetics and Photochemical Data for Use in Atmospheric Studies, Evaluation No. 18, JPL Publication 15-10, Jet Propulsion Laboratory, Pasadena, available at: http: //jpldataeval.jpl.nasa.gov, last access: 31 October 2015.

Caridade, P. J. S. B., Horta, J.-Z. J., and Varandas, A. J. C.: Implications of the $\mathrm{O}+\mathrm{OH}$ reaction in hydroxyl nightglow modeling, Atmos. Chem. Phys., 13, 1-13, https://doi.org/10.5194/acp-131-2013, 2013.

Dalin, P., Perminov, V., Pertsev, N., and Romejko, V.: Updated long-term trends in mesopause temperature, airglow emissions, and noctilucent clouds, J. Geophys. Res.-Atmos., 125, e2019JD030814, https://doi.org/10.1029/2019JD030814, 2020.

Damiani, A., Storini, M., Santee, M. L., and Wang, S.: Variability of the nighttime $\mathrm{OH}$ layer and mesospheric ozone at high latitudes during northern winter: influence of meteorology, Atmos. Chem. Phys., 10, 10291-10303, https://doi.org/10.5194/acp-10-102912010, 2010.

Gao, H., Xu, J., and Wu, Q.: Seasonal and QBO variations in the $\mathrm{OH}$ nightglow emission observed by TIMED/SABER, J. Geophys. Res., 115, A06313, https://doi.org/10.1029/2009JA014641, 2010.

Gao, H., Xu, J., Ward, W., and Smith, A. K.: Temporal evolution of nightglow emission responses to SSW events observed by TIMED/SABER, J. Geophys. Res., 116, D19110, https://doi.org/10.1029/2011JD015936, 2011.

Good, R. E.: Determination of atomic oxygen density from rocket borne measurements of hydroxyl airglow, Planet. Space Sci., 24, 389-395, https://doi.org/10.1016/0032-0633(76)90052-0, 1976.

Grygalashvyly, M.: Several notes on the $\mathrm{OH}^{*}$ layer, Ann. Geophys., 33, 923-930, https://doi.org/10.5194/angeo-33-923-2015, 2015.

Grygalashvyly, M.: Grygalashvyly_et_al_ANGEO_2020, available at: http://ra.rshu.ru/files/Grygalashvyly_et_al_ANGEO_2020, last access: 27 November 2020.

Grygalashvyly, M. and Sonnemann, G. R.: Note on Consistency between Kalogerakis-Sharma Mechanism (KSM) and TwoStep Mechanism of Atmospheric Band Emission, Earth Planets Space, 72, 187, https://doi.org/10.1186/s40623-020-01321-z, 2020.

Grygalashvyly, M., Sonnemann, G. R., Lübken, F.-J., Hartogh, P., and Berger, U.: Hydroxyl layer: Mean state and trends at midlatitudes, J. Geophys. Res., 119, 12391-12419, https://doi.org/10.1002/2014JD022094, 2014.

Hartogh, P., Sonnemann, G. R., Grygalashvyly, M., Li, S., Berger, U., and Lübken, F.-J.: Water vapor measurements at ALOMAR over a solar cycle compared with model 
calculations by LIMA, J. Geophys. Res., 114, D00I17, https://doi.org/10.1029/2009JD012364, 2010.

Hartogh, P., Jarchow, C., Sonnemann, G. R., and Grygalashvyly, M.: Ozone distribution in the middle latitude mesosphere as derived from microwave measurements at Lindau $\left(51.66^{\circ} \mathrm{N}, 10.13^{\circ} \mathrm{E}\right)$, J. Geophys. Res., 116, D04305, https://doi.org/10.1029/2010JD014393, 2011.

Holmen, S. E., Dyrland, M. E., and Sigernes, F.: Longterm trends and the effect of solar cycle variations on mesospheric winter temperatures over Longyearbyen, Svalbard $\left(78^{\circ} \mathrm{N}\right)$, J. Geophys. Res.-Atmos., 119, 6596-6608, https://doi.org/10.1002/2013JD021195, 2014.

Kalicinsky, C., Knieling, P., Koppmann, R., Offermann, D., Steinbrecht, W., and Wintel, J.: Long-term dynamics of $\mathrm{OH}^{*}$ temperatures over central Europe: trends and solar correlations, Atmos. Chem. Phys., 16, 15033-15047, https://doi.org/10.5194/acp-1615033-2016, 2016.

Kaye, J. A.: On the possible role of the reaction $\mathrm{O}+\mathrm{HO}_{2} \rightarrow \mathrm{OH}+\mathrm{O}_{2}$ in $\mathrm{OH}$ airglow, J. Geophys. Res., 93, 285-288, https://doi.org/10.1029/JA093iA01p00285, 1988.

Kremp, C., Berger, U., Hoffmann, P., Keuer, D., and Sonnemann, G. R.: Seasonal variation of middle latitude wind fields of the mesopause region - a comparison between observation and model calculation, Geophys. Res. Lett., 26, 1279-1282, https://doi.org/10.1029/1999GL900218, 1999.

Kulikov, M. Y., Feigin, A. M., and Sonnemann, G. R.: Retrieval of water vapor profile in the mesosphere from satellite ozone and hydroxyl measurements by the basic dynamic model of mesospheric photochemical system, Atmos. Chem. Phys., 9, 81998210, https://doi.org/10.5194/acp-9-8199-2009, 2009.

Kulikov, M. Y., Belikovich, M. V., Grygalashvyly, M., Sonnemann, G. R., Ermakova, T. S., Nechaev, A. A., and Feigin, A. M.: Nighttime ozone chemical equilibrium in the mesopause region, J. Geophys. Res., 123, 3228-3242, https://doi.org/10.1002/2017JD026717, 2018a.

Kulikov, M. Y., Nechaev, A. A., Belikovich, M. V., Ermakova, T. S., and Feigin, A. M.: Technical note: Evaluation of the simultaneous measurements of mesospheric $\mathrm{OH}, \mathrm{HO}_{2}$, and $\mathrm{O}_{3}$ under a photochemical equilibrium assumption - a statistical approach, Atmos. Chem. Phys., 18, 7453-7471, https://doi.org/10.5194/acp-18-7453-2018, 2018 b.

Kulikov, M. Y., Nechaev, A. A., Belikovich, M. V., Vorobeva, E. V., Grygalashvyly, M., Sonnemann, G. R., and Feigin, A. M.: Boundary of Nighttime Ozone Chemical Equilibrium in the Mesopause Region from SABER Data: Implications for Derivation of Atomic Oxygen and Atomic Hydrogen, Geophys. Res. Lett., 46, 997-1004, https://doi.org/10.1029/2018GL080364, 2019.

Le Texier, H., Solomon, S., and Garcia, R. R.: Seasonal variability of the OH Meinel bands, Planet. Space Sci., 35, 977-989, https://doi.org/10.1016/0032-0633(87)90002-X, 1987.

Limpasuvan, V., Richter, J. H., Orsolini, Y. J., Stordal, F., and Kvissel, O.-K.: The roles of planetary and gravity waves during a major stratospheric sudden warming as characterized by WACCM, J. Atmos. Sol.-Terr. Phy., 78-79, 84-98, https://doi.org/10.1016/j.jastp.2011.03.004, 2012.

Limpasuvan, V., Orsolini, Y. J., Chandran, A., Garcia, R. R., and Smith, A. K.: On the composite response of the MLT to major sudden stratospheric warming events with ele- vated stratopause, J. Geophys. Res.-Atmos., 121, 4518-4537, https://doi.org/10.1002/2015JD024401, 2016.

Liu, G., Shepherd, G. G., and Roble, R. G.: Seasonal variations of the nighttime $\mathrm{O}\left({ }^{1} \mathrm{~S}\right)$ and $\mathrm{OH}$ airglow emission rates at mid-to-high latitudes in the context of the large-scale circulation, J. Geophys. Res., 113, A06302, https://doi.org/10.1029/2007JA012854, 2008.

López-González, M. J., Rodríguez, E., Wiens, R. H., Shepherd, G. G., Sargoytchev, S., Brown, S., Shepherd, M. G., Aushev, V. M., López-Moreno, J. J., Rodrigo, R., and Cho, Y.-M.: Seasonal variations of $\mathrm{O}_{2}$ atmospheric and $\mathrm{OH}(6-2)$ airglowand temperature at mid-latitudes from SATI observations, Ann. Geophys., 22, 819-828, https://doi.org/10.5194/angeo-22-819-2004, 2004.

López-González, M. J., Rodríguez, E., Shepherd, G. G., Sargoytchev, S., Shepherd, M. G., Aushev, V. M., Brown, S., García-Comas, M., and Wiens, R. H.: Tidal variations of $\mathrm{O}_{2}$ Atmospheric and $\mathrm{OH}(6-2)$ airglow and temperature at midlatitudes from SATI observations, Ann. Geophys., 23, 35793590, https://doi.org/10.5194/angeo-23-3579-2005, 2005.

Lopez-Gonzalez, M. J., Garcia-Comas, M., Rodriguez, E., LopezPuertas, M., Shepherd, M. G., Shepherd, G. G., Sargoytchev, S., Aushev, V. M., Smith, S. M., Mlynczak, M. G., Russell, J. M., Brown, S., Cho, Y.-M., and Wiens, R. H.: Ground-based mesospheric temperatures at mid-latitude derived from $\mathrm{O}_{2}$ and $\mathrm{OH}$ airglow SATI data: Comparison with SABER measurements, J. Atmos. Sol.-Terr. Phy., 69, 2379-2390 https://doi.org/10.1016/j.jastp.2007.07.004, 2007.

López-González, M. J., Rodríguez, E., García-Comas, M., Costa, V., Shepherd, M. G., Shepherd, G. G., Aushev, V. M., and Sargoytchev, S.: Climatology of planetary wave type oscillations with periods of 2-20 days derived from $\mathrm{O}_{2}$ atmospheric and $\mathrm{OH}(6-2)$ airglow observations at mid-latitude with SATI, Ann. Geophys., 27, 3645-3662, https://doi.org/10.5194/angeo27-3645-2009, 2009.

Lübken, F.-J., Berger, U., and Baumgarten, G.: Stratospheric and solar cycle effects on long-term variability of mesospheric ice clouds, J. Geophys. Res., 114, D00106, https://doi.org/10.1029/2009JD012377, 2009.

Lübken, F.-J., Berger, U., and Baumgarten, G.: Temperature trends in the midlatitude summer mesosphere, J. Geophys. Res., 118, 13347-13360, https://doi.org/10.1002/2013JD020576, 2013.

Makhlouf, U. B., Picard, R. H., and Winick, J. R.: Photochemicaldynamical modeling of the measured response of airglow to gravity waves. 1. Basic model for OH airglow, J. Geophys. Res., 100, 11289-11311, https://doi.org/10.1029/94JD03327, 1995.

Marsh, D. R., Smith, A. K., Mlynczak, M. G., and Russell III, J. M.: SABER observations of the $\mathrm{OH}$ Meinel airglow variability near the mesopause, J. Geophys. Res., 111, A10S05, https://doi.org/10.1029/2005JA011451, 2006.

Mlynczak, M. G., Hunt, L. A., Mast, J. C., Marshall, B. T., Russell III, J. M., Smith, A. K., Siskind, D. E., Yee, J.-H., Mertens, C. J., Martin-Torres, F. J., Thompson, R. E., Drob, D. P., and Gordley, L. L.: Atomic oxygen in the mesosphere and lower thermosphere derived from SABER: Algorithm theoretical basis and measurement uncertainty, J. Geophys. Res.-Atmos., 118, 57245735, https://doi.org/10.1002/jgrd.50401, 2013a.

Mlynczak, M. G., Hunt, L. A., Mertens, C. J., Marshall, B. T., Russell III, J. M., Lopez-Puertas, M., Smith, A. K., Siskind, D. E., Mast, J. C., Thompson, R. E., and Gordley, L. L.: Radiative and 
energetic constraints on the global annual mean atomic oxygen concentration in the mesopause region, J. Geophys. Res.-Atmos., 118, 5796-5802, https://doi.org/10.1002/jgrd.50400, 2013b.

Mlynczak, M. G., Hunt, L. A., Marshall, B. T., Mertens, C. J., Marsh, D. R., Smith, A. K., Russell, J. M., Siskind, D. E., and Gordley, L. L.: Atomic hydrogen in the mesopause region derived from SABER: Algorithm theoretical basis, measurement uncertainty, and results, J. Geophys. Res., 119, 3516-3526, https://doi.org/10.1002/2013JD021263, 2014.

Morton, K. W. and D. F. Mayers, D. F.: Numerical Solution of Partial Differential Equations, Cambridge University Press, Cambridge, UK, 1994.

Pertsev N. N., Andreyev A. B., Merzlyakov E. G., and Perminov V. I.: Mesosphere-thermosphere manifestations of strato-spheric warmings: joint use of satellite and ground-based measurements, Sovremennye problemy distantsionnogo zondirovaniya Zemli iz kosmosa, 10, 93-100, available at: http://jr.rse.cosmos.ru/article. aspx?id=1154\&lang=eng (last access: 31 December 2013), 2013.

Popov, A. A., Gavrilov, N. M., Andreev, A. B., and Pogoreltsev, A. I.: Interannual dynamics in intensity of mesoscale hydroxyl nightglow variations over Almaty, Solar-Terr. Phys., 4, 63-68, https://doi.org/10.12737/stp-42201810, 2018.

Popov, A. A., Gavrilov, N. M., Perminov, V. I., Pertsev, N. N., and Medvedeva, I. V.: Multi-year observations of mesoscale variances of hydroxyl nightglow near the mesopause at Tory and Zvenigorod, J. Atmos. Sol-Terr. Phy., 205, 1-8, https://doi.org/10.1016/j.jastp.2020.105311, 2020.

Reid, I. M., Spargo, A. J., and Woithe, J. M.: Seasonal variations of the nighttime $\mathrm{O}\left({ }^{1} \mathrm{~S}\right)$ and $\mathrm{OH}(8-3)$ airglow intensity at Adelaide, Australia, J. Geophys. Res.-Atmos., 119, 6991-7013, https://doi.org/10.1002/2013JD020906, 2014.

Reid, I. M., Spargo, A. J., Woithe, J. M., Klekociuk, A. R., Younger, J. P., and Sivjee, G. G.: Seasonal MLT-region nightglow intensities, temperatures, and emission heights at a Southern Hemisphere midlatitude site, Ann. Geophys., 35, 567-582, https://doi.org/10.5194/angeo-35-567-2017, 2017.

Reisin, E., Scheer, J., Dyrland, M. E., Sigernes, F., Deehr, C. S., Schmidt, C., Höppner, K., Bittner, M., Ammosov, P. P., Gavrilyeva, G. A., Stegman, J., Perminov, V. I., Semenov, A. I., Knlieling, P., Koomann, R., Shiokawa, K., Lowe, R. P., Lopez-Gonzalez, M. J., Rodriguez, E., Zhao, Y., Taylor, M. J., Buriti, R. A., Espy, P. E., French, W. J., Eichmann, K.-U., Burrows, J. P., and von Savigny, C.: Traveling planetary wave activity from mesopause region airglow temperatures determined by the Network for the Detection of Mesospheric Change (NDMC), J. Atmos. Sol.-Terr. Phy., 119, 71-82, https://doi.org/10.1016/j.jastp.2014.07.002, 2014.

Russell, J. P., Ward, W. E., Lowe, R. P., Roble, R. G., Shepherd, G. G., and B. Solheim, B.: Atomic oxygen profiles (80 to $115 \mathrm{~km}$ ) derived from Wind Imaging Interferometer/Upper Atmospheric Research Satellite measurements of the hydroxyl and greenline airglow: Local time-latitude dependence, J. Geophys. Res., 110, D15305, https://doi.org/10.1029/2004JD005570, 2005.

Shepherd, G. G., Thuillier, G., Cho, Y.-M., Duboin, M.-L., Evans, W. F. J., Gault, W. A., Hersom, C., Kendall, D. J. W., Lathuillère, C., Lowe, R. P., McDade, I. C., Rochon, Y. J., Shepherd, M. G., Solheim, B. H., Wang, D.-Y., and Ward, W. E.: The Wind Imaging Interferometer (WINDII) on the Upper Atmosphere Research
Satellite: A 20 year perspective, Rev. Geophys., 50, RG2007, https://doi.org/10.1029/2012RG000390, 2012.

Shepherd, M. G., Cho, Y.-M., Shepherd, G. G., Ward, W., and Drummond, J. R.: Mesospheric temperature and atomic oxygen response during the January 2009 major stratospheric warming, J. Geophys. Res., 115, A07318, https://doi.org/10.1029/2009JA015172, 2010.

Shimazaki, T.: Minor constituents in the middle atmosphere, D. Reidel Publishing Company, Dordrecht, Holland, 1985.

Smith, A. K., Marsh, D. R., Russell III, J. M., Mlynczak, M. G., Martin-Torres, F. J., and Kyrölä, E.: Satellite observations of high nighttime ozone at the equatorial mesopause, J. Geophys. Res., 113, D17312, https://doi.org/10.1029/2008JD010066, 2008.

Smith, A. K., Lopez-Puertas, M., Garcia-Comas, M., and Tukiainen, S.: SABER observations of mesospheric ozone during NH late winter 2002-2009, Geophys. Res. Lett., 36, L23804, https://doi.org/10.1029/2009GL040942, 2009.

Smith, A. K., Marsh, D. R., Mlynczak, M. G., and Mast, J. C.: Temporal variation of atomic oxygen in the upper mesosphere from SABER, J. Geophys. Res., 115, D18309, https://doi.org/10.1029/2009JD013434, 2010.

Sonnemann G. and Grygalashvyly, M.: The slow-down effect in the nighttime mesospheric chemistry of hydrogen radicals, Adv. Space Res., 65, 2800-2807, https://doi.org/10.1016/j.asr.2020.03.025, 2020.

Sonnemann, G. R., Hartogh, P., Jarchow., C., Grygalashvyly, M., and Berger, U.: On the winter anomaly of the nightto-day ratio of ozone in the middle to upper mesosphere in middle to high latitudes, Adv. Space Res., 40, 846-854, https://doi.org/10.1016/j.asr.2007.01.039, 2007.

Sonnemann, G. R., Hartogh, P., Grygalashvyly, M., Li, S., and Berger, U.: The quasi 5-day signal in the mesospheric water vapor concentration in high latitudes in 2003 - a comparison between observations at ALOMAR and calculations, J. Geophys. Res., 113, D04101, https://doi.org/10.1029/2007JD008875, 2008.

Sonnemann, G. R., Hartogh, P., Berger, U., and Grygalashvyly, M.: Hydroxyl layer: trend of number density and intra-annual variability, Ann. Geophys., 33, 749-767, https://doi.org/10.5194/angeo-33-749-2015, 2015.

Takahashi, H. and Batista, P. P.: Simultaneous measurements of $\mathrm{OH}(9,4),(8,3),(7,2), 6,2)$, and $(5,1)$ bands in the airglow, J. Geophys. Res., 86, 5632-5642, https://doi.org/10.1029/JA086iA07p05632, 1981.

Takahashi, H., Clemesha, B. R., and Batista, P. P.: Predominant semi-annual oscillation of the upper mesospheric airglow intensities and temperatures in the equatorial region, J. Atmos. Terr. Phys., 57, 407-414, https://doi.org/10.1016/00219169(94)E0006-9, 1995.

Takahashi, H., Batista, P. P., Buriti, R. A, Gobbi, D., Nakamura, T., Tsuda, T., and Fukao, S.: Response of the airglow OH emission, temperature and mesopause wind to the atmospheric wave propagation over Shigaraki, Japan, Earth Planets Space, 51, 863-875, https://doi.org/10.1186/BF03353245, 1999.

Taylor, M. J., Espy, P. J., Baker, D. J., Sica, R. J., Neal, P. C., and Pendleton Jr., W. R.: Simultaneous intensity, temperature and imaging measurements of short period wave structure in the OH nightglow emission, Planet. Space Sci., 39, 1171-1188, https://doi.org/10.1016/0032-0633(91)90169-B, 1991. 
Varandas, A. J. C.: Reactive and non-reactive vibrational quenching in $\mathrm{O}+\mathrm{OH}$ collisions, Chem. Phys. Lett., 396, 182-190, https://doi.org/10.1016/j.cplett.2004.08.023, 2004.

Wachter, P., Schmidt, C., Wüst, S., and Bittner, M.: Spatial gravity wave characteristics obtained from multiple $\mathrm{OH}(3-1)$ airglow temperature time series, J. Atmos. Sol.-Terr. Phy., 135, 192-201, https://doi.org/10.1016/j.jastp.2015.11.008, 2015.

Walcek, C. J.: Minor flux adjustment near mixing ratio extremes for simplified yet highly accurate monotonic calculation of tracer advection, J. Geophys. Res., 105, 9335-9348, https://doi.org/10.1029/1999JD901142, 2000.
Wiens, R. H., Moise, A., Brown, S., Sargoytchev, S., Peterson, R. N., Shepherd, G. G., Lopez-Gonzalez, M. J., Lopez-Moreno J. J., and Rodrigo R.: SATI: A spectral airglow tempera-ture imager, Adv. Space Res., 19, 677-680, https://doi.org/10.1016/S02731177(97)00162-2, 1997.

Xu, J., Smith, A. K., Jiang, G., Gao, H., Wei, Y., Mlynczak, M. G., and Russell III, J. M.: Strong longitudinal variations in the $\mathrm{OH}$ nightglow, Geophys. Res. Lett., 37, L21801, https://doi.org/10.1029/2010GL043972, 2010.

Xu, J., Gao, H., Smith, A. K., and Zhu, Y.: Using TIMED/SABER nightglow observations to investigate hydroxyl emission mechanisms in the mesopause region, J. Geophys. Res., 117, D02301, https://doi.org/10.1029/2011JD016342, 2012. 